Original Research Paper

\title{
Pendampingan Implementasi Pembelajaran Guided Discovery Melalui Lesson Study for Learning Community (LSLC) untuk Peningkatan Kemampuan Berpikir Kritis Kimia Siswa SMA Zonasi Narmada Kabupaten Lombok Barat
}

\author{
Muntari $^{1 *}$, Muti'ah ${ }^{1}$, Syarifa Wahidah Al Idrus ${ }^{1}$, Supriadi $^{1}$

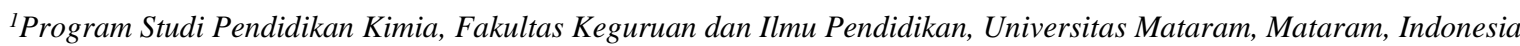

https://doi.org/10.29303/jpmpi.v3i2.603

Sitasi: Muntari., Muti'ah., Idrus S. W., \& Supriadi. (2021). Pendampingan Implementasi Pembelajaran Guided Discovery Melalui Lesson Study for Learning Community (LSLC) untuk Peningkatan Kemampuan Berpikir Kritis Kimia Siswa SMA Zonasi Narmada Kabupaten Lombok Barat. Jurnal Pengabdian Magister Pendidikan IPA, 4(1)

\section{Article history}

Received: 05 Desember 2020

Revised: 30 Desember 2020

Accepted: 29 Januari 2021

*Corresponding Author:

Muntari, Program Studi

Pendidikan Kimia, Fakultas

Keguruan dan Ilmu Pendidikan,

Universitas Mataram, Mataram, Indonesia

Email: muntari16@unram.ac.id

\begin{abstract}
The implementation of the learning process is always oriented towards the mastery of competence by students. One of the important competencies possessed by students is high order thinking skills (HOTS). Based on the results of observations in several high schools in the Narmada zoning, West Lombok district, it was obtained: (1) The ability of student's critical thinking in chemistry on average was still low; (2) Students do not have the opportunity to develop the potential for critical thinking skills in learning due to the use of unsuitable learning models; (3) The ability of teachers to apply learning models that can improve students' critical thinking skills is still low; and (4) Teachers carry out learning individually so that it is difficult to evaluate the learning process as a result of continuous improvement of learning difficult to implement. The solution offered in this community service activity is in the form of teacher assistance in implementing zoning-based of lesson study for learning communities (LSLC) to improve students' critical thinking skills in chemistry. The targets of this community service activity are teachers of chemistry subjects from SMA Negeri 1 Narmada, SMA Negeri 2 Narmada, SMA Negeri 1 Lingsar, and SMA NW Narmada. This activity was carried out with a training approach, learning practice, and reflection. This activity was carried out in two stages: the first stage is socialization and workshop about LSLC, then in the second stage the lesson study (LS) practice. The results achieved from this activity are: (1) Students' critical thinking skills in chemistry subjects need to be continuously improved through various learning innovations, one of which is by implementing guided discovery learning; (2) Increased understanding of teachers regarding the principles, benefits, and scope of the lesson study and LSLC appropriately; and (3) The increased enthusiasm of teachers to implement lesson study-based learning improvements which consist of planning stages (plan), implementation of learning and observation (do), and reflection (see), and re-design
\end{abstract}

Keywords: Critical Thinking Skills; Guided Discovery; LSLC

\section{Pendahuluan}

etiap pelaksanaan proses pembelajaran selalu berorientasi pada penguasaan kompetensi oleh siswa. Salah satu kompetensi yang penting dimiliki oleh siswa adalah kemampuan berpikir tingkat tinggi (high order thingking skills, HOTS). Kemampuan berpikir tingkat tinggi terdiri dari pemikiran logis, pemikiran kritis dan kemampuan 
penalaran yang merupakan kemampuan dasar dalam kehidupan sehari-hari, terlepas dari prestasi akademisnya (Marshall \& Horton, 2011). Dalam kegiatan pengabdian kepada masyarakat ini kemampuan berpikir tingkat tinggi yang akan ditingkatkan adalah kemampuan berpikir kritis menurut Facione (2015).

Dalam mengembangkan kemampuan berpikir kritis siswa dalam pembelajaran dibutuhkan model pembelajaran yang dapat mengoptimalkan aktivitas fisik dan mental siswa dalam mengkonstruksi pengetahuan sendiri sesuai konsep pembelajaran yang berbasis pendekatan konstruktivisme (Muntari, 2015). Salah satu model pembelajaran yang dapat mengembangkan potensi kemampuan berpikir kritis siswa adalah model guided discovery (Melani (2012), Qurniati dkk (2015), dan Muntari dkk, 2018). Langkah-langkah dalam model pembelajaran penemuan terbimbing (guided discovery), terdiri atas pemberian rangsangan (stimulation), mengidentifikasi masalah (problem statement), pengumpulan data (data collection), pengolahan data (data processing), pembuktian (verification), dan menarik kesimpulan (generalization) (Hamalik, 2007). Melalui langkahlangkah aktivitas penemuan (discovery) tersebut membuat siswa lebih aktif dalam proses pembelajaran sehingga memungkinkan siswa mampu menguasai indikator-indikator kemampuan berpikir kritis (Purwanto, 2012 dan Muntari dkk, 2019). Berdasarkan hasil penelitian kemampuan berpikir kritis berkorelasi positif dengan hasil belajar (Ramdani dan Badriah, 2018). Oleh karena itu kualitas kemampuan berikir kritis dapat digunakan sebagai indikator kualitas hasil belajar.

Berdasarkan hasil observasi hasil belajar siswa di SMA zonasi Narmada Kabupaten Lombok Barat masih rendah yang mengindikasikan kemampuan berpikir kritis siswa juga rendah (Data SMA Negeri 1 Narmada, 2019). Rendahnya kemampuan berpikir kritis siswa di SMA zonasi Narmada akibat kualitas proses pembelajaran rendah. Hal ini desebabkan oleh model pembelajaran yang biasa diterapkan kurang sesuai untuk pengembangan kemampuan berpikir kritis siswa dan kemampuan guru dalam menggunakan model pembelajaran untuk mengembangkan kemampuan berpikir kritis siswa masih rendah.

Masih rendahnya kemampuan guru dalam melaksanakan proses pembelajarn tidak terlepas dari sistem yang berlaku di sekolah, yaitu guru dalam mengajar dilakukan secara individu. Guru dalam melaksanakan proses pembelajaran secara individu sulit secara bersamaan melakukan evaluasi terhadap kualitas proses pembelajaran karena lebih fokus pada penyampaian materi pembelajaran. Hal ini berdampak pada lemahnya usaha untuk perbaikan kualitas proses pembelajaran secara berkelanjutan. Permasalahan ini dapat diatasi jika dalam proses pembelajaran dilakukan secara kolaboratif dengan melibatkan guru lain terutama yang bidang ilmunya sama sebagai observer untuk menilai kualitas proses pembelajaran.

Salah satu model pengelolaan pembelajaran yang dilakukan secara kolaboratif mulai dari proses perencaan pembelajaran (plan), pelaksanaan pembelajaran ( $d o$ ) dan evaluasi serta refleksi (see) adalah lesson study. Lesson study digambarkan sebagai suatu proses yang terdiri dari langkahlangkah berikut: (1) perencanaan pembelajaran secara kolaboratif; (2) menerapkan pembelajaran yang direncanakan; (3) mendiskusikan hasil observasi pembelajaran; (4) merevisi rencana pelajaran (opsional); (5) mengajarkan kembali pembelajaran yang direvisi (opsional); dan (6) berbagi pemikiran tentang pembelajaran yang direvisi (Fernandez dan Yoshida (2004) dalam Saito dkk (2015)). Pemahaman tentang lesson study telah dimiliki oleh sebagian guru di SMA zona Narmada. Namun demikian pengetahuan tersebut belum diimplementasikan dalam pembelajaran.

Lesson study telah berkembang menjadi lesson study for learning community (LSLC). LSLC mempromosikan lingkungan di mana anak-anak belajar bersama, guru dihormati sebagai model pembelajaran yang profesional, dan orang tua dalam komunitas yang lebih besar berkumpul dan berpartisipasi dalam restorasi pendidikan. Komunitas pembelajaran semacam itu membutuhkan pembelajaran kolaboratif di semua ruang kelas dan mendorong kolegialitas di ruang guru dengan kemitraan di antara para guru sebagai komponen penting dari kesuksesan (Saito dkk (2015). Melalui learning community (LC), satuan pendidikan diharapkan dapat mengatasi kendala yang muncul di kelas melalui kerja kolaborasi antar guru, kepala sekolah, dinas pendidikan, dan orang tua. Melalui LSLC memberikan kesempatan setiap peserta didik dapat terpenuhi hak belajarnya dan merasa "nyaman" belajar di sekolah.

Untuk maksud membantu peningkatan kemampuan guru mata pelajaran kimia di zonasi 
Narmada Kabupaten Lombok Barat diperlukan pendampingan implementasi pembelajaran guided discovery melalui lesson study for learning community (LSLC) untuk peningkatan kemampuan berpikir kritis kimia siswa. Tim pelaksana kegiatan pengabdian kepada masyarakat memiliki kapasitas dan pengalaman untuk melakukan pendampingan kegiatan tersebut. Sejumlah penelitian dan pengabdian kepada masyarakat terkait implementasi pembelajaran inqury maupun discovery telah dilakukan dengan memberikan hasil yang positif (Mutiah dkk (2013) dan Muntari dkk (2018, 2019)). Pengalaman melaksanaan pendampingan lesson study telah dimiliki oleh tim pelaksana, di antaranya adalah dalam penelitian oleh Muntari (2017) dan Muti'ah dan Sukib (2017), pengabdian kepada masyarakat oleh Muntari (2016), pelatihan lesson study oleh Muntari (2019). Pengalaman pengembangan kemampuan berpikir tingkat tinggi, khususnya kemampuan berpikir kritis telah dilakukan oleh Muntari $(2015,2016$, 2017, 2018, dan 2019). Semua informasi kapasitas dan pengalaman tim pelaksana tercantum dalam biodata tim pelaksana).

Oleh karena itu tim tertarik melaksanakan kegiatan pengabdian kepada masyarakat dengan judul "Pendampingan Implementasi Pembelajaran Guided Discovery melalui Lesson Study for Learning Community (LSLC) untuk Peningkatan Kemampuan Berpikir Kritis Kimia Siswa SMA Zonasi Narmada Kabupaten Lombok Barat".

\section{Metode}

Kegiatan pengabdian kepada masyarakat ini diikuti oleh penggiat pembelajaran kimia dari SMA di wilayah zonasi Narmada, Kabupaten Lombok Barat, mahasiswa dan alumni program studi Pendidikan Kimia FKIP Unram. Peserta yang dilibatkan dalam kegiatan ini sebanyak 16 orang yang terdiri atas 12 (dua belas) guru kimia, satu kepala SMA, satu pengawas mata pelajaran kimia, dan dua mahasiswa.

Kegiatan pengabdian kepada masyarakat bagi guru kimia kelompok MGMP zonasi Narmada, Kabupaten Lombok Barat dalam mengimplementasikan pembelajaran guided discovery melalui lesson study for learning community (LSLC) untuk meningkatkan kemampuan berpikir kritis kimia siswa dilaksanakan dengan pendekatan pelatihan, praktik pembelajaran, dan refleksi. Kegiatan ini dilaksanakan dalam dua tahap, yakni pada tahap pertama sosialisasi LSLC dan workshop lesson study, kemudian pada tahap kedua praktik lesson study (LS). Lesson study (LS) sendiri dilaksnakan dalam dua siklus yang terdiri atas PLAN, DO, SEE (refleksi).

\section{Hasil dan Pembahasan}

Kegiatan pengabdian kepada masyarakat bagi guru kimia kelompok MGMP zonasi Narmada, Kabupaten Lombok Barat dalam mengimplementasikan pembelajaran guided discovery melalui lesson study for learning community (LSLC) untuk meningkatkan kemampuan berpikir kritis kimia siswa. Kegiatn ini diawali dengan analisis situasi dengan cara observasi dan wawancara kepada guru-guru kimia, peserta didik, pimpinan sekolah, dan pihak-pihak lain yang terkait. Berdasarkan hasil analisis situasi ini diperoleh permasalahan utama yang dihadapi guru-guru kimia sebagai berikut:

a) Kemampuan berpikir kritis siswa pada mata pelajaran kimia yang ditunjukkan oleh kesulitan siswa memberikan argumentasi menjawab soal dengan tingkat berpikir tinggi.

b) Siswa kurang mendapat kesempatan untuk mengembangkan potensi kemampuan berpikir kritis dalam pembelajaran akibat penggunanaan model pembelajaran yang kurang sesuai.

c) Kemampuan guru dalam menerapkan modelmodel pembelajaran yang dapat meningkatkan kemampuan berpikir kritis siswa masih rendah.

d) Guru melaksanakan pembelajaran secara individu sehingga sulit dalam mengevaluasi proses pembelajaran akibatnya perbaikan pembelajaran secara berkesinambungan sulit dilaksanakan.

Berdasarkan permasalahan yang terjadi pada sekolah mitra, solusi yang ditawarkan dalam kegiatan pengabdian kepada masyarakat ini berupa pendampingan implementasi pembelajaran guided discovery melalui lesson study for learning community (LSLC) untuk peningkatan kemampuan berpikir kritis kimia siswa. Lesson study telah berkembang menjadi lesson study for learning community (LSLC). LSLC mempromosikan lingkungan di mana anak-anak belajar bersama, guru dihormati sebagai model pembelajaran yang profesional, dan orang tua dalam komunitas yang 
lebih besar berkumpul dan berpartisipasi dalam restorasi pendidikan (Saito dkk (2015).

Salah satu model pengelolaan pembelajaran yang dilakukan secara kolaboratif mulai dari proses perencaan pembelajaran (plan), pelaksanaan pembelajaran (do) dan evaluasi serta refleksi (see) adalah lesson study. Lesson study digambarkan sebagai suatu proses yang terdiri dari langkahlangkah berikut: (1) perencanaan pembelajaran secara kolaboratif; (2) menerapkan pembelajaran yang direncanakan; (3) mendiskusikan hasil observasi pembelajaran; (4) merevisi rencana pelajaran (opsional); (5) mengajarkan kembali pembelajaran yang direvisi (opsional); dan (6) berbagi pemikiran tentang pembelajaran yang direvisi (Fernandez dan Yoshida (2004) dalam Saito dkk (2015)). Pemahaman tentang lesson study telah dimiliki oleh sebagian guru di SMA zona Narmada. Namun demikian pengetahuan tersebut belum diimplementasikan dalam pembelajaran.

Kegiatan pengabdian masyarakat ini dilaksanakan dalam dua tahap, yakni pada tahap pertama sosialisasi dan workshop tentang LSLC, kemudian pada tahap kedua praktik lesson study (LS). Sosialisasi dan workshop diikuti oleh 16 peserta yang terdiri atas 12 (dua belas) guru kimia, satu orang kepala SMA, satu orang pengawas mata pelajaran, dan dua orang mahasiswa.

Materi yang dibahas dalam sosialisasi LSLC adalah: (1) membangun sekolah bermutu berbasis zonasi melalui lesson study for learning community (LSLC), dan (2) tahapan kolaboratif dalam LSLC. Selama pembahasan kedua materi tersebut, peserta mengikuti dengan hikmat dan antusias, banyak peserta yang bertanya untuk memperdalam pemahannya terkait materi. Semula rencana pembahasan materi hanya selama satu jam, berkembang menjadi dua jam. LSLC dirasakan merupakan pengetahuan baru, di mana selama ini peserta telah memiliki pemahaman tentang lesson study. Dari materi ini peserta memiliki pemahaman bahwa untuk meningkatan mutu pembelajaran diperlukan kolaborasi, baik antar peserta didik, bersama guru-guru di sekolah, bersama guru-guru di sekolah lain, dan kolaborasi bersama masyarakat sekitar.

Materi yang dibahas dalam workshop lesson study adalah: (1) chapter and lesson design, (2) teknik observasi saat pembelajaran, (3) teknik refleksi, dan (4) praktik pelaksanaan open class dan refleksi. Selama pembahasan keempat materi tersebut, peserta mengikuti dengan antusias. Banyak pertanyaan yang disampaikan oleh peserta sehingga membutuhkan waktu yang lebih banyak untuk menjelaskan dengan memberi contoh terkait materi yang dipertanyakan. Banyak hal yang menarik bagi peserta terkait dengan keempat materi yang dibahas. Hal ini disebabkan oleh pemahaman tentang lesson study yang dirasakan baru oleh peserta, sekaligus untuk memperjelas atau meluruskan pemahaman peserta yang selama ini masih kurang tepat. Misalnya sejumlah peserta menganggap kegiatan lesson study sama dengan kegiatan penelitian tindakan kelas.

Kegiatan pengabdian kepada masyarakat pada tahap kedua adalah praktik lesson study (LS). Kegiatan ini sedianya direncanakan akan dilaksanakan dua siklus, namun karena situasi pandemi COVID-19 kegiatan ini hanya dilaksnakan dalam satu siklus. Kegiatan praktik lesson study juga hanya dilakukan di sekolah masing-masing peserta, tanpa mengundang peserta dari sekolah lain untuk mengikuti kegiatan open class dan refleksi. Tahapan lesson study, yang terdiri atas tahap perencanaan (plan), tahap pelaksanaan pembelajaran dan observasi $(d o)$, dan tahap refleksi (see), serta re-design telah dipraktikan dengan berbagai pengalaman lapangan.

Kegiatan pengabdian kepada masyarakat ini difokuskan pada pendampingan implementasi pembelajaran guided discovery melalui lesson study for learning community (LSLC) untuk meningkatkan kemampuan berpikir kritis kimia siswa. Berdasarkan pengalaman serangkaian kegiatan yang berupa sosialiasi LSLC, workshop lesson study, dan praktik pelaksanaaan lesson study, peserta diharapkan memiliki pengetahuan yang tepat tentang lesson study dan LSLC. Selain itu melalui praktik lesson study diharapkan peserta memiliki pengalaman praktis dalam melaksanakan lesson study.

Untuk mendapatkan informasi terkait kegiatan sosialisasi LSLC, workshop lesson study, dan praktik pelaksanaan lesson study, peserta diberikan angket isian. Berdasarkan angket tersebut diperoleh informasi pasca kegiatan pengabdian kepada masyarakat sebagai berikut:

a) Semua peserta memahami prinsip, manfaat, dan ruang lingkup lesson study, lesson study for learning community, dan penelitian tindakan kelas. 
b) Sebagian besar peserta telah memahami tahapan lesson study, yang terdiri atas tahap perencanaan (plan), tahap pelaksanaan pembelajaran dan observasi (do), dan tahap refleksi (see), serta re-design.

c) Peserta berharap kegiatan LSLC dapat dilaksanakan secara berkelanjutan baik secara mandiri di sekolah maupun berkolaborasi dengan guru-guru dari sekolah lain dengan dukungan masing-masing pimpinan sekolah.

Peserta menyadari bahwa untuk meningkatkan mutu pembelajaran dan kompetensi guru maupun peserta didik di era globalisasi dan tuntutan keterampilan abad 21 dapat dicapai melalui kolaborasi, diantaranya dengan menghidupkan LSLC.

\section{Kesimpulan}

Kegiatan pengabdian kepada masyarakat ini difokuskan pada pendampingan implementasi pembelajaran guided discovery melalui lesson study for learning community (LSLC) untuk meningkatkan kemampuan berpikir kritis kimia siswa. Berdasarkan pengalaman serangkaian kegiatan yang berupa sosialiasi LSLC, workshop lesson study, dan praktik pelaksanaaan lesson study dapat disimpulkan beberapa hal berikut:

a) Kemampuan berpikir kritis siswa pada mata pelajaran kimia perlu secara terus menerus diupayakan peningkatannya melalui berbagai inovasi pembelajaran, salah satunya adalah dengan menerapkan pembelajaran guided discovery.

b) Meningkatnya pemahaman guru terkait prinsip, manfaat, dan ruang lingkup lesson study (LS) dan lesson study for learning community (LSLC) secara tepat.

c) Meningkatnya semangat guru untuk melaksanakan perbaikan pembelajaran berbasis lesson study yang terdiri atas tahapan perencanaan (plan), pelaksanaan pembelajaran dan observasi (do), dan refleksi (see), serta redesign.

\section{Saran}

Berdasarkan pengamatan dan jawaban angket pasca kegiatan pengabdian kepada masyarakat ini dapat disarankan beberapa hal berikut:

a) Aktivitas LSLC harus digerakkan secara terencana dan terorganisir oleh para pihak yang berkepentingan terhadap peningkatan mutu pembelajaran, terutama sekolah.

b) Sekolah secara bersama-sama dengan sekolah lain dalam zonasinya melaksanakan kegiatan lesson study secara kolaborasi dalam rangka peningkatan mutu pembelajaran.

c) Dalam rangka menghidupkan LSLC untuk peningkatan mutu pembelajaran sangat dibutuhkan dukungan dari sekolah, masyarakat, dan dinas pendidikan.

\section{Ucapan Terima Kasih}

Ucapan terima kasih disampaikan kepada beberapa pihak yang telah mendukung terlaksananya penelitian ini, di antaranya:

1. Rektor Universitas Mataram yang telah memberikan dukungan dana PNBP untuk kegiatan pengabdian kepada masyarakat tersebut.

2. Kepala SMAN 1 Narmada, Kepala SMAN 2 Narmada, Kepala SMAN 1 Lingsar, dan Kepala SMA NW Narmada yang telah memfasilitasi terlaksananya kegiatan pengadian kepada masyarakat tesebut.

\section{Daftar Pustaka}

Facione, P.A. (2015). Critical Thinking: What It Is and Why It Counts. California: Measured Reasons and The California Academic Press.

Hamalik, O. (2007). Proses Belajar Mangajar. Jakarta: Bumi Aksara.

Marshall, J. C., \& Horton, R. M. (2011). The relationship of teacher-facilitated, inquirybased instruction tostudent higher-order thinking. School Science and Mathematics, 111(3), 93-101.

Melani, R. (2012). Pengaruh Metode Guided Discovery Learning terhadap Sikap Ilmiah dan Hasil Belajar Kognitif Biologi Siswa SMA Negeri 7 Surakarta Tahun Pelajaran 2011/2012.

(online), http://eprints.uns.ac.id/13651/1/1409-31351-SM. pdf. Diakses pada tanggal 08 Maret 2016.

Muntari, Siahaan, J. Supriadi. (2018). Implementasi Strategi Pembelajaran Kimia Berbasis Diskoveri untuk Optimalisasi Pencapaian 
Hasil Belajar. Laporan Penelitian. LPPM Universitas Mataram

Muntari. (2015). Implementasi strategi pembelajaran berbasis inquiri-diskoveri untuk optimalisasi pencapaian hasil belajar kimia sesuai kurikulum 2013. Prosiding Seminar Nasional Pendidikan Sains. Surabaya, Unesa, 1114-1121.

Muntari; Haris, M; Sukib; dan Yanti, E. (2019). Pengaruh model pembelajaran penemuan terbimbing (guided discovery) terhadap kemampuan berpikir kritis dan Hasil belajar kimia siswa kelas X SMAN 4 Mataram. Jurnal Ilmiah Profesi Pendidikan. Vol. 4 (2), hal. 100-105.

Muntari dan Purwoko, A.A. (2017). Penerapan Pembelajaran Berbasis Lesson Study untuk Meningkatkan Kualitas Proses dan Hasil Belajar Kimia Pada Siswa SMA Negeri 1 Kediri Lombok Barat. Laporan pengabdian. Universitas Mataram

Muti'ah dan Sukib. (2017). Pengembangan pembelajaran ekstraksi pelarut dan kromatografi melalui lesson study. Laporan penelitian. Universitas Mataram.

Purwanto, C.E. (2012). Penerapan Model Pembelajaran Guided Discovery pada Materi Pemantulan Cahaya untuk Meningkatkan Berpikir Kritis. Unnes Physics Education Journal. 1(1): 26-32.

Qurniati, D, Andayani, Y, dan Muntari. (2015). Peningkatan Keterampilan Berpikir Kritis Melalui Model Pembelajaran Discovery Learning. JPPIPA. Juli 2015. Vol. 1 No. 2: 58-69.

Ramdani, D; Badriah, L. (2018). Korelasi antara Kemampuan Berpikir Kritis dengan Hasil Belajar Siswa melalui Model Pembelajaran Inkuiri Terbimbing Berbasis Blended Learning Pada Materi Sistem Respirasi Manusia. Jurnal Bio Educatio, Vol. 3 (2), hlm. 37- 44.

Saito, E; Murase, M; Tsukui, E; \& Yeo, John. (2015). Lesson Study for Learning Community: A Guide to Sustainable School Reform. London: Routledge. 